\title{
Building Tax Capacity in Developing Countries
}

\begin{abstract}
The agenda for the Third International Conference on Financing for Development suggests there will be less focus on aid, and more on how developing countries can generate their own financial resources for development. Governments will be urged to tax more effectively, and donors will be called upon to help build capacity in developing country tax administrations. While there is considerable evidence that donor support can enhance tax capacity, success is not guaranteed. In order for such programmes to be effective, they will need to be responsive to local contexts, be designed to prioritise building trust, offer long-term mentoring, target the right range of institutions, and facilitate South-South collaboration.
\end{abstract}

'No developing country that has set out credible plans for strengthening domestic revenue mobilization and tackling corruption will lack for international support to make these plans a reality.

(FINANCING FOR DEVELOPMENT ZERO DRAFT)

A wide variety of donors and international organisations currently provide different types of support for building tax capacity. The more prominent are the large multilateral organisations like the International Monetary Fund (IMF) and the Organisation for Economic Co-operation and Development (OECD) and bilateral donors such as Germany, Norway, the UK, and the USA. In recent years, new donors have entered the field, and there are growing signs of uncoordinated, overlapping or competitive activity. This can be counter-productive, as it saps the capacity of the countries which are supposed to be benefitting. Experience suggests that coordination is most successful if the recipient government takes the lead. For example, the Tanzania Revenue Authority's Planning and Modernisation Office effectively coordinates all donor funding and projects.

In developing countries, revenue authorities are now able to recruit talented and educated people, and there is no shortage of courses for them to attend. Many developing countries have their own tax training institutes, and international organisations, private companies and some donors offer a wide variety of short courses. However, many organisations that provide capacity building services to tax administrations are rooted in OECD countries rather than the global South, and they correspondingly offer training and advice that fits with their own values and priorities. For example, the OECD is keen to provide training on applying its arm's length principle, although there exist alternatives that may make more sense for developing countries.

The greatest challenge for tax administrations is retention of skilled staff, particularly those with scarce and valuable skills, especially in IT, accounting, and forensic auditing. This is a general problem for the public sector everywhere in the world, but it is particularly acute in low-income countries where there is a smaller pool of people with these skills, and so they are sometimes 'poached' by private firms. Although revenue authorities already pay their staff well compared to the rest of the civil service, there are cases in which higher remuneration for particularly valuable staff is justified, since losing them can have costly repercussions. Further, there is significant scope for improving policies and management practices that provide staff with more personal and professional satisfaction, and rewards them based on their performance.

The capacity of tax administrations varies widely among developing countries, and this means that different capacity building strategies are called for depending on their given institutional context. For example, the Kenya Revenue Authority will benefit from OECD support on making use of advance pricing agreements, which are complex mechanisms for combating transfer mispricing by multinational firms. By contrast, Sierra Leone has no transfer pricing legislation in place and the revenue authority does not have access to the information or the skills needed to start addressing this problem. While tailormade strategies will be required in each country, we have four key recommendations for donors seeking to build tax capacity that apply across all contexts. 


\section{Recommendations}

\section{Tax capacity does not depend solely on tax administrations}

It is important that donors do not view tax-collecting agencies as the only relevant bodies for targeting capacity building efforts. Tax policy units within ministries of finance are equally deserving of attention. Staff in these units are paid less than employees in semi-autonomous revenue authorities, and their responsibilities are significant: evaluating the impacts of tax policies on the economy and proposing reforms, making revenue projections and setting collection targets. Building capacity in the judiciary is also important, as any disputed tax cases will end up in the courts. Donors should consider measures to inform and empower parliamentarians, parliamentary committees and citizens in order to promote the passing of better legislation and greater accountability. In contexts where tax collection is characterised by coercion and corruption, increased popular and legislative scrutiny can encourage better collection processes, which in turn may increase compliance and lead to higher and more sustainable revenue streams.

\section{Mentoring is better than training}

While targeted short-term training can be useful, building longer-term mentoring relationships has proven to be immensely fruitful. Staff from the national revenue agencies of donor countries can be very effective providers as they 'speak the same language' as their counterparts. For example, the Norwegian Tax Administration signed a four-year agreement of institutional cooperation with the Zambian Revenue Authority. Norwegian officers visit for two weeks each quarter, and work jointly with their Zambian counterparts on specific cases, helping them to 'learn by doing'. While this collaboration has been a great success, this type of work depends upon the willingness donor tax administrations to commit skilled staff to what might be seen as a low priority activity. Consultant organisations can also provide this type of mentorship, but may find it more difficult to provide staff continuity.

\section{Facilitate South-South Cooperation}

Cooperation between developing countries is advantageous because it is less supply-driven, and advisors are more likely to have relevant experience in similar contexts. While South-South cooperation has been increasing through bodies like the Inter-American Centre of Tax Administrations and the African Tax Administration Forum, donors can accelerate this trend. They can facilitate 'triangular cooperation' by providing funds for more advanced developing countries to offer capacity building to countries that are further behind. Donors could also establish an independent fund devoted to financing South-South cooperation on a demand-led basis. This would empower decision-makers in the South to choose their sources of technical assistance, and could be structured along the lines of the International Organisation of Supreme Audit Institutions.

\section{Capacity building is centrally about building trust}

A focus on building trust will encourage donors to be sensitive to local contexts and needs and willing to commit to long-term support and incremental progress. It will also help them to seek a balance between solving problems in the short-term, while also analysing options for supporting institutional reform in the longer-term.
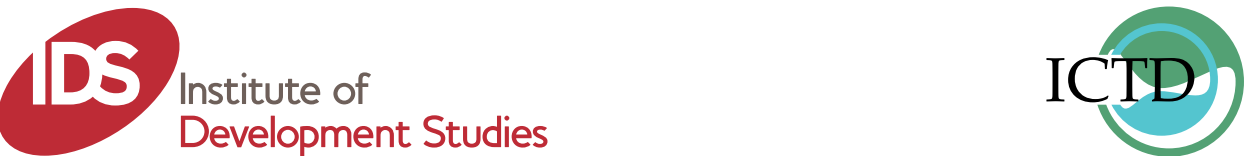

IDS Policy Briefings are published by the Institute of Development Studies and aim to provide high quality analysis and practical recommendations for policymakers on important development issues. To subscribe: www.ids.ac.uk/idspolicybriefings

Institute of Development Studies, Brighton BN1 9RE UK

T+44 (0) 1273606261 F + 44 (0) 1273621202 E ids@ids.ac.uk W www.ids.ac.uk y twitter.com/IDS_UK \#idspolicy $\mathbf{f}$ facebook.com/idsuk

\section{Further reading}

Fjeldstad, O. (2014) 'Tax and

Development: Donor Support

to Strengthen Systems in

Developing Countries', Public

Administration and Development 34: 182-93

Fjeldstad, O. and Heggstad, K. (2012) Tax Administrations Working Together: Documentation of the Initial Phase of the Norwegian Tax

Administration and the Revenue

Authorities in Mozambique

Tanzania and Zambia, Bergen:

Chr. Michelsen Institute

Fordelone, T. (2009) Triangular Co-operation and Aid Effectiveness:

Can Triangular Co-operation Make Aid More Effective?, Paris: OECD

IMF, OECD, UN and World

Bank (2011) Supporting the

Development of More Effective

Tax Systems: A Report to the G-20

Development Working Group,

Washington: IMF

\section{Credits}

This IDS Policy Briefing was

written by Mick Moore

Odd-Helge Fjeldstad, Jan

Isaksen, Olav Lundstøl,

Rhiannon McCluskey and

Wilson Prichard. It was edited

by Hannah Corbett and Emilie

Wilson. It was produced as part

of the International Centre for

Tax and Development research

program at the Institute of

Development Studies (IDS),

supported by the UK

Department for International

Development and the

Norwegian Agency for

Development Cooperation.

The opinions expressed are

those of the authors and do not necessarily reflect the views of IDS.

Readers are encouraged to quote and reproduce material from the IDS Policy Briefing series. In return, IDS requests due acknowledgement and quotes referenced as above.

(C) Institute of Development Studies, 2015 ISSN 1479-974X 